\title{
RECURSOS METAFICCIONAIS PARA (RE)LER A HISTÓRIA EM OS ANJOS CONTAM HISTÓRIAS, DE LUIZ ANTONIO AGUIAR
}

\author{
Silvani Lopes Lima (IFRS) \\ Fabiane Verardi Burlamaque (UPF)
}

Resumo: Este artigo apresenta uma análise da obra Os Anjos Contam Histórias, de Luiz Antonio Aguiar, buscando demonstrar como sua construção ficcional promove uma (re)leitura, através de estratégias próprias da metaficção historiográfica, do episódio histórico da Inconfidência Mineira, ocorrido durante o ciclo do ouro, em Minas Gerais. O texto utiliza, como mote mais específico, o mistério em torno do roubo da cabeça de Tiradentes, líder da revolta. A narrativa é protagonizada pelo casal Manoel Francisco Lisboa, filho de Aleijadinho, e Joanna Lopes, os quais, com a idade de apenas quinze anos, se envolvem com os conjuradores e passam a viver arriscadas peripécias. As diversas experiências por que passam os protagonistas não só os torna mais unidos como também faz com que amadureçam na adversidade. $\mathrm{O}$ autor, ao destacar que a narrativa é baseada em fatos históricos, mas que estes foram livremente usados e combinados ao sabor da invenção, lembra-nos que todo e qualquer relato a que temos acesso, seja ele ficcional ou historiográfico, é discursivo, constituído de fatos textualizados e não de acontecimentos em si, sendo portanto sempre parcial e limitado, pois é contado de um determinado ponto de vista. Assim, buscamos demonstrar como se mesclam e se dissipam aspectos da fiç̧ão e da história nesta trama contada por anjos.

Palavras-chave: Ficção; História; Metaficção; Narrativa Juvenil.

Abstract: This article presents an analysis of the book Os Anjos Contam Histórias, by Luiz Antonio Aguiar, aiming to demonstrate how the fictional construction promotes a (re)reading, thorough strategies of the historiographic metafiction, of the historic episode of Inconfidência Mineira, which occurred during the gold cycle, in Minas Gerais. The text uses, as a more specific motive, the mystery surrounding the theft of Tiradentes' head, leader of the revolt. The narrative is stared in by the couple Manoel Francisco Lisboa, son of Aleijadinho, and Joanna Lopes, which, at the age of only fifteen, who live risky adventures by getting 
involved with conspirators The diverse experiences that protagonists go through not only make them more united but also make them mature in adversity. The author, by highlighting that the narrative is based on historical facts, but that they were freely united and combined according to his imagination, and that it is just a version of the story told by the angels. Thus, he reminds us that all and any report that we have access, fictional or historiographic, is discursive, constituted by textualized facts and not by real facts, being, therefore, they are always limited and partial because they are told by a determined point of view. Therefore, we seek to demonstrate how aspects of fiction and history merge and dissipate in this plot told by angels.

Keywords: Fiction; History; Metafiction; Juvenile narrative.

\section{DO PARATEXTO AO TEXTO}

A obra Os Anjos Contam Histórias, de autoria de Luiz Antonio Aguiar e ilustrações de Rubem Filho, foi publicada pela editora Melhoramentos em 2012, tendo sido finalista na categoria "Juvenil" do Prêmio Jabuti, concedido pela Câmara Brasileira do Livro, no ano de 2013. A história é protagonizada pelo casal Manuel Francisco Lisboa e Joanna Lopes. Manuel Francisco é filho de Antônio Francisco Lisboa, conhecido pelo epíteto de Aleijadinho, e Joanna Lopes, sua melhor amiga e depois esposa, é filha de uma parteira e benzedeira famosa entre a população local por seus dons de cura. Ambos vivem na cidade de Vila Rica - atual Ouro Preto -, na província das Minas Gerais, conhecem-se desde criança e possuem um vínculo afetivo muito forte, que nasce com uma grande amizade e se transforma em um amor para a vida inteira. 
Entretanto, não só Manuel Francisco, filho de Aleijadinho, ganha evidência na narrativa. O próprio artista mineiro, enquanto grande personalidade histórica, também é transformado em personagem ficcional, tendo muitos aspectos de sua vida e obra revelados, sejam estes factuais ou fictícios. E, em torno dessas personagens centrais, outras vão ganhando notoriedade à medida que a história se desenrola, tais como o governador geral de Minas e seus aliados e os inconfidentes, entre estes o próprio Tiradentes.

Destacamos alguns elementos paratextuais da obra em estudo para, em seguida, nos aprofundarmos mais na narrativa em si. A capa do livro é trabalhada em tons de marrom (fundo e pequenos arabescos nas bordas externas) e preto (arabesco maior, em cujo pé vemos a reprodução de três anjos e dentro do qual aparece o título da obra). Os textos verbais constantes na capa (nome do autor no alto, título no centro, nome do ilustrador abaixo do título, e logo da editora no pé da página) aparecem na cor branca. Os anjos reproduzidos representam aqueles esculpidos por Aleijadinho no frontispício da Igreja de São Francisco de Assis, em Ouro Preto. A presença de inúmeros anjos em toda a obra do escultor mineiro fez com que estes passassem a ser apontados como uma espécie de assinatura do artista, e a referência aos anjos, como criaturas divinas que conversam 
com Aleijadinho, sendo seus mentores e símbolo da sua obra, é constante ao longo de toda a narrativa de Os Anjos Contam Histórias. Logo, no conjunto, a capa remete ao estilo barroco e à arte própria do período, já que esta aparece profundamente imbricada com a história narrada através da referência ao trabalho de Aleijadinho.

Ainda, entre os elementos paratextuais precedentes à narrativa, destacamos a página de epígrafes e uma pequena reportagem retirada do site $O$ Globo, em 15 de maio de 2012, intitulada "Onde está a cabeça de Tiradentes?". Na página de epígrafes, constam uma observação do escritor sobre o caráter ficcional da obra, alertando que a sua "base histórica foi livremente usada e combinada à invenção, ao sabor da trama" (AGUIAR, 2012, p.8); um fragmento do "Epicédio II - a morte de Salício", de Glauceste Satúrnio, pseudônimo do poeta árcade Cláudio Manuel da Costa, excerto este que remete à ressurreição da persona poética Salício, por meio da poesia, lembrando-nos do poder da arte de eternizar o homem; e uma frase retirada de um texto crítico de Mário de Andrade acerca da obra de Aleijadinho, na qual o escritor modernista fala sobre a capacidade de reinventar o mundo do "mestiço" artista mineiro. A reportagem apresentada no início da obra, por sua vez, aponta-nos a base histórica que inspirou a narrativa ficcional: o mistério em torno do sumiço 
da cabeça do líder da Inconfidência Mineira, Joaquim José da Silva Xavier, o qual ficou conhecido como Tiradentes.

Além desses paratextos iniciais, existem ilustrações que abrem partes e capítulos da obra, algumas delas ocupando duas páginas, as quais são todas trabalhadas em preto e branco e representam ações transcorridas na obra, assim como enfatizam paisagens típicas de Minas, com seus morros, pedras e ladeiras. Em virtude de nosso viés de análise, entretanto, não nos debruçaremos sobre essas imagens por não nos parecer que revelem dados importantes para a nossa leitura. Passaremos, assim, aos paratextos que aparecem ao final da narrativa: "Contexto histórico, artístico e cultural"; "Referências bibliográficas"; "Sobre o autor" e "Sobre o ilustrador". Os Anjos Contam Histórias é uma obra especialmente endereçada ao público juvenil e livremente inspirada em acontecimentos históricos e, nesse sentido, é possível afirmar que esses últimos paratextos possuem um viés mais pedagógico. De toda maneira, isso não desmerece a qualidade do texto, que apresenta uma narrativa bem elaborada, com uma boa tessitura de enredo. Ademais, os dados sobre autor e ilustrador dizem bastante sobre o perfil da obra: o primeiro é apresentado como um premiado escritor, que produziu inúmeras obras de ficção, algumas premiadas por entidades ligadas à literatura infantil 
e juvenil (LIJ), e muitas delas recuperando temas de viés historiográfico; o segundo, como um experiente ilustrador, também com muitos trabalhos na LIJ, o qual, por ser mineiro, é um profundo conhecedor das cidades históricas de Minas Gerais e um apaixonado pelo "passado de glórias e riquezas contrastantes com o horror da escravidão e opressão colonial" (AGUIAR, 2012, p.231) daquela região.

O paratexto contextual apresenta, rapidamente, o pano de fundo histórico sobre o qual se constrói o enredo ficcional da obra: a revalorização de Aleijadinho pelo grupo de intelectuais ligados ao Modernismo, em especial Mário de Andrade, cuja publicação do ensaio $O$ Aleijadinho impulsionou o reconhecimento da obra do artista barroco; os indícios de que Aleijadinho possa ter tido alguma ligação com os inconfidentes, especialmente devido a sua possível amizade com o poeta Cláudio Manuel da Costa e ao próprio espírito libertário de sua obra; a opressão sofrida pela colônia em virtude da falência de Portugal, que se tornara dependente do ouro do Brasil, e o consequente sentimento de indignação que provavelmente contaminou aqueles indivíduos que sonhavam com a liberdade e a prosperidade para o país. As "referências bibliográficas", por sua vez, apontam o repertório cultural com o qual a narrativa em questão dialoga: biografia e outros textos sobre Aleijadinho e 
a obra poética de Cláudio Manuel da Costa. Como não poderia deixar de ser, a obra Os Anjos Contam Histórias apresenta, então, um diálogo entre a ficção de boa qualidade e o contexto histórico e cultural de Minas Gerais e do próprio Brasil.

Também fica explícita a principal fonte na qual o texto de Aguiar vai buscar os dados biográficos sobre Aleijadinho, nada menos do que em Rodrigo Bretas, o primeiro e, por isso, mais importante biógrafo do artista mineiro. A biografia feita por Bretas, no entanto, foi apontada por seu tom romanceado, na qual fantasia e realidade se misturam na recuperação dos dados sobre a vida de Aleijadinho. Outros estudiosos da vida e obra do escultor mineiro ressaltam esse aspecto. Conforme John Bury,

[a]s tradicionais histórias a seu respeito, narradas por Rodrigo Ferreira Brêtas, estão mais próximas da realidade do que a própria verdade, como os comentários sobre o temperamento do mulato [...].

São essas histórias, fantasiosas porém simbólicas, que dão um colorido particular à interpretação dos últimos trabalhos do Aleijadinho como expressões de protesto social e de anseio pela independência que libertasse o país de uma classe dominante brutal e escravagista. (2006, p.100-101)

Da mesma maneira, Luiz Armando Bagolin faz alusão a isso em texto no qual comenta a obra Aleijadinho e o 
aeroplano: o paraíso barroco e o herói nacional, de Guiomar de Grammont, referindo-se ao mito criado em torno da figura de Aleijadinho. Nas palavras dele,

Guiomar se interessa, particularmente, em seu livro, pelos critérios que mobilizaram a construção do Aleijadinho como representação autoral, genuinamente brasileira e genial, a partir de meados do século XIX, nos discursos literários, históricos e críticos.

Tal construção tem início, segundo a autora, com o discurso de Rodrigo José Ferreira Bretas [...].

A invenção do Aleijadinho na persona do entalhador Antônio Francisco Lisboa, que provavelmente circulou pelas Minas Gerais do XVIII, coube a Bretas [...], tendo investido a composição de sua biografia em gênero epidítico [...]. Bretas, professor de retórica, foi hábil em montar uma biografia que move o leitor em direção à dor, sublime, da vida, deformada e finita, em confronto com a arte bela e infinda, operando por disjunções, quanto ao ethos, na composição do personagem Aleijadinho. (2009, p.353-354)

Nesse mesmo viés, a crítica que Mário de Andrade produz sobre a obra de Aleijadinho encerra a ideia de "redescobrir" o artista e de "construir" um lugar para sua obra. Portanto, dado o caráter ficcional da narrativa de Os Anjos Contam Histórias, essa dúvida que paira em relação aos dados da vida de Aleijadinho, no sentido de haver muita incerteza sobre o 
que é fato e o que é fantasia, acaba muito mais auxiliando na composição da história do que representando algum tipo de problema.

Sobre a composição narrativa da obra, esta é introduzida pela parte inicial de uma carta de Manuel Francisco endereçada à Joanna, na qual ele rememora acontecimentos aos quais vamos tendo acesso durante a narração. Essa primeira parte consiste em uma espécie de prólogo, e recebe o título de "Visões". A carta está datada como "Eremitério de Nossa Senhora Mãe dos Homens, Serra do Caraça, Capitania de Minas Gerais, (19) de março de 1931" e seus trechos estão distribuídos ao longo da narrativa: na abertura e distribuídos nos capítulos seis, dez e onze, totalizando oito fragmentos. Nesse texto, Manuel Francisco recupera e organiza suas memórias que são transpostas em forma epistolar. O ano é 1831, quando ele vive em um eremitério, e, a partir deste ponto, relembra acontecimentos ocorridos há cerca de quarenta anos, os quais têm início no ano de 1792, quando ele e Joanna possuíam apenas quinze anos e cometeram um ato espantoso: roubaram a cabeça de Tiradentes da praça do pelourinho, no centro de Vila Rica.

Os acontecimentos retomados na carta remetem à história que constitui a narrativa principal, a qual é dividida em quatro partes: parte I, "Rebeldes", com os capítulos 
1. A noite espantosa, 2. Terra dos anjos, 3. Glauceste Satúrnio e 4. A filha da bruxa; parte II, "Heróis", composta pelos capítulos 5. Meu querido amigo, 6. Gênios e heróis, 7. Coração espremido, 8. Com cara de santarrão e 9. Despedidas; parte III, "Profetas", formada pelos capítulos 10. Santuário e 11. Um rasgo nos céus; e parte IV, “Anjos”, contendo o capítulo 12. O pai, o filho e o filho do filho. Encontramos ainda um breve epílogo, sob o título de "Memória", fechando a narrativa.

Denominamos narrativa principal aquela transcorrida majoritariamente no final do século XVIII, no ano de 1792, em Vila Rica e seus arredores. Essa mesma história tem sua continuidade no século XIX, no ano de 1812, em Vila Rica e Congonhas do Campos, avançando finalmente para o ano de 1857, na mesma Vila Rica, quando nos deparamos com Joanna já idosa e viúva. O casal de protagonistas Manuel Francisco e Joanna se arriscam em perigosas missões ao se envolverem com membros da Inconfidência Mineira. Por apresentar inúmeros flashbacks, podemos dizer que o tempo da narrativa é psicológico. Esses flashbacks, no interior da narrativa principal, mostram acontecimentos relacionados com os personagens, fatos imediatamente anteriores ou ocorridos há alguns anos. Esses recuos temporais retomam ações transcorridas nos anos de 1767, 1784, 1785, 1787 e 1789. Também temos transcrições de outras cartas escritas 
pelos protagonistas, as quais constituem muitas vezes uma espécie de diário íntimo dos personagens. Todas as cartas se apresentam grafadas em itálico e sob um fundo que reproduz papel envelhecido, representando documentos antigos, ou memórias, inseridos no interior da narrativa. Nessas cartas, identificamos avanços temporais, em relação ao ano de 1792, para 1797 e 1831. O ano de 1792 é aquele no decorrer do qual, como dissemos, transcorrem a maioria dos acontecimentos, e duas dessas cartas são trocadas entre o casal neste ínterim, servindo-lhes como instrumento de comunicação durante um período em que, por estarem correndo risco de serem capturados, não conseguiam se encontrar pessoalmente.

Notamos que os flashbacks não se apresentam em forma de memórias, são também narrados por um narrador onisciente e sempre marcados graficamente, como uma forma de alertar o leitor para o recuo no tempo. Eles aparecem com recuo maior em relação à margem esquerda da página e são intercalados por marcadores em forma de pequenos arabescos ou datados.

É importante observar que essas analepses revelam acontecimentos importantes que implicam nas ações que transcorrem durante a narrativa principal. São momentos 
da infância dos protagonistas, fatos marcantes da vida dos demais personagens e reuniões ocorridas entre os conjuradores. Ou, então, ações mais próximas do presente, como é o caso do baile em casa do governador, mas que deflagraram uma determinada reação dos heróis da narrativa. Conforme formos recuperando pontos da narrativa que sejam relevantes para a nossa análise, iremos retomando esses recuos temporais e suas implicações na narrativa.

\section{DA HISTÓRIA À FICÇÃO: UMA INVENÇÃO DOS ANJOS}

A leitura de Os Anjos Contam Histórias evidencia a tentativa de organizar fatos e documentos em busca de um arranjo do enredo pelo narrador. Isso se revela na transcrição de documentos (no todo ou em parte) para o interior da narrativa, não só as cartas trocadas entre os protagonistas, conforme já mencionamos, como também parte da sentença de Tiradentes, proferida no Rio de Janeiro em 18 de abril de 1792 (AGUIAR, 2012, p.45), e um panfleto distribuído por um grupo do qual Manuel Francisco participou, no ano de 1831, na cidade do Rio de Janeiro, durante a revolta popular contra D. Pedro I (p.82). No informativo, Tiradentes é reverenciado como herói do povo e símbolo do desejo de independência e liberdade para o país. Entre esses documentos, misturam-se aqueles de caráter ficcional (cartas e panfleto) com um de 
procedência histórica (parte da sentença de Tiradentes). 0 que se percebe, ao fim, é que não é possível demarcar onde terminam os dados históricos e começam os imaginativos ou ficcionais, é como se ocorresse uma fusão entre fato e fantasia nessa leitura da história pela ficção no interior da narrativa, provocando mesmo um questionamento sobre essas aparentes oposições.

Isso é referido em diferentes momentos da obra: na página de epígrafes, onde o autor insere um comentário alertando que a base histórica em que se assentam os acontecimentos mencionados no texto não impedem que eles sofram um rearranjo ao sabor da invenção; quando o narrador titubeia sobre como teriam transcorrido as ações que narra, alegando que "deve ter acontecido assim, mas também pode ter sido diferente. Enfim... Foi como os anjos contaram essa história" (AGUIAR, 2012, p.55); quando, ao final da narrativa, deparamo-nos com o primeiro biógrafo de Aleijadinho, Rodrigo Bretas, uma das "Referências bibliográficas" da obra, entrevistando a personagem Joanna, já idosa e viúva. Notemos um trecho da narrativa que reproduz parte do diálogo transcorrido entre os personagens nesse encontro:

- Antes, só para eu saber, senhor Bretas disse ela, finalmente dirigindo-se a ele. -0 senhor acredita em anjos? 
- Receio que não, dona Joanna. Por quê? Isso importa? Quero dizer... o que têm anjos a ver com nossa história?

Ela sorriu. Trocou uma piscadela com os anjinhos em sua mão... a tríade de pedrasabão que Aleijadinho esculpira para Manuel Francisco, e, sem tentar responder à pergunta de Bretas, disse:

- É isso, tudo eu não lhe conto. Tem coisa que é segredo, e ainda não chegou a hora de o pessoal do mundo saber. Talvez um dia... Mas vamos entrar, que eu vou the fazer um chá. E o que o senhor vai ouvir vai querer passar adiante. Vai, sim. Ah! A propósito, senhor Bretas, noutros lugares não sei, mas aqui, em Vila Rica, os anjos contam histórias. (2012, p.220)

O fragmento acima sugere para o leitor quem é o narrador que está por trás da história narrada: o próprio Bretas, que a teria recolhido junto à Joanna e está transmitindo o que ouviu. Isso poderia explicar o fato de o relato dos acontecimentos vir acompanhado de transcrições de cartas e outros documentos como uma estratégia metaficcional de dar verificabilidade à história narrada.

Rodrigo Bretas, poucos anos após a morte de Aleijadinho, escreveu a primeira biografia sobre o artista mineiro. Nesse texto, considerado por outros estudiosos do tema como bastante romanceado, Bretas menciona vários episódios da vida e da obra do escultor que estão presentes em Os 
Anjos Contam Histórias, entre estes a existência do filho Manuel Francisco que seria fruto da relação de Aleijadinho com uma escrava; o casamento deste filho com Joanna Lopes; a menção de que Joanna, nora do escultor, seria o único membro da sua família ainda vivo na ocasião em que foi redigida aquela biografia; além, é claro, dos mistérios que cercaram a vida do artista, que foi acometido por uma grave doença a certa altura da vida, a qual the provocava dores terríveis e foi lhe deformando fisicamente, isso o levou a se isolar cada vez mais do convívio social, provocando a curiosidade e a repulsa das pessoas que com ele conviveram (BRETAS Apud BURY, 2006).

Dessa maneira, a obra de Aguiar explora a figura histórica Aleijadinho, tornando-a também central para a narrativa. O personagem é apresentado como alguém misterioso, dotado de um dom divino, capaz de falar com os anjos, que são a própria inspiração para a sua obra, já que a magnitude de sua arte não pode ser explicada sendo ele um mulato, com instrução limitada a poucos mestres locais, o qual nunca se afastou do seu lugar de nascimento para estudar, não frequentou escolas de educação formal, não tendo, portanto, acesso aos mestres da arte universais. Além disso, a sua aparência extremamente assustadora devido 
a uma doença que o desfigurava cotidianamente, um dado bastante ressaltado em biografias sobre o artista, é também enfatizada na obra, aumentando o ar de mistério que o cerca. Olhemos a epígrafe, retirada de Rodrigo Bretas, que abre a parte I da obra, reforçando essa informação:

As pálpebras infamaram-se e, permanecendo nesse estado, ofereciam à vista sua parte interior, perdeu quase todos os dentes, a boca entortou-se e, como sucede frequentemente ao estuporado, o queixo e o lábio inferior abateram-se um pouco; assim o olhar do infeliz adquiriu certa expressão sinistra e de ferocidade, que chegava mesmo a assustar quem quer que o encarasse inopinadamente. Esta circunstância e tortura da boca o tornavam de um aspecto asqueroso e medonho.

[...]

Tanta miséria ousando aliar-se a tanta poesia!

Rodrigo José Ferreira Bretas, Traços biográficos relativos ao finado Antônio Francisco Lisboa, distinto escultor mineiro, mais conhecido pelo apelido de Aleijadinho. (AGUIAR, 2012, p.21)

Mais adiante, na abertura do segundo capítulo, temos nova epígrafe, também retirada de Bretas, que complementa a descrição de Aleijadinho: “...ficou sendo geralmente conhecido pelo apelido - Aleijadinho. Tinha um certo aparelho de couro, ou madeira, continuamente aplicado aos 
joelhos, e neste estado admirava-se a coragem e agilidade com que ousava subir altas escadas de carpinteiro. Rodrigo Bretas" (AGUIAR, 2012, p.49). Tanto o primeiro quanto o segundo fragmento selecionados trazem uma descrição recheada de detalhes que revelam Aleijadinho como uma figura bastante antagônica: aterradora pela aparência e admirável pela habilidade artística.

Ao mesmo tempo, se os dados biográficos do Aleijadinho se assentam em textos existentes sobre o artista, alguns destes mencionados nas referências bibliográficas listadas ao final do livro, a versão politicamente engajada do entalhador fica por conta da criação ficcional no interior da obra. A personalidade histórica recriada ficcionalmente é uma figura que atua politicamente junto aos inconfidentes de 1789, compartilhando com estes o sonho de liberdade para o Brasil colonial. Ao apresentar Aleijadinho como um dos inconfidentes, a história de Os Anjos Contam Histórias provoca, ironicamente, uma inversão nas relações sociais rígidas existentes no Brasil daquele tempo, especialmente na região das Minas Gerais, onde os mulatos ou mestiços (filhos de negros com brancos) não eram reconhecidos socialmente. Em ensaio sobre a vida e a obra de Aleijadinho, John Bury (2006) nota que a política adotada nas Minas 
Gerais, com o fim de proteger a exploração do ouro na região, garantindo que a riqueza extraída fosse para as mãos da Coroa portuguesa, era extremamente rígida, com a adoção de medidas drásticas. Um dos grandes medos dos governadores locais era de uma possível rebelião da população de escravos, que somava um alto percentual na região das minas. Assim, segundo o autor,

o medo e a desconfiança que os colonos brancos sentiam se estendiam até mesmo aos mulatos. Nenhuma pessoa que tivesse sangue negro até a quarta geração tinha permissão de obter qualquer cargo municipal, proibição que não se aplicava em nenhum outro lugar do Brasil colonial. (2006, p.23)

Sendo provável, em sua opinião, que Aleijadinho tenha se ressentido muito com essa discriminação.

O movimento da Inconfidência ou Conjuração Mineira foi liderado por membros da classe alta da sociedade mineira, nesse contexto, portanto, era inconcebível que estivesse, entre os ilustres conjuradores, um indivíduo cujo sangue negro corria nas veias. Porém, no texto ficcional, Aleijadinho não só participa do grupo como também é respeitado e admirado entre os conjuradores, tanto que é atribuído ao artista a articulação das principais ações de rebeldia dentro da história, inclusive a mais ousada delas, o roubo da 
cabeça de Tiradentes do local em que estava exposta após a execução da pena aplicada ao inconfidente. No primeiro capítulo, o narrador onisciente relata sobre a noite em que Manuel Francisco e Joanna praticaram o audacioso roubo, da Praça do Pelourinho, no centro de Vila Rica:

Joanna já imaginava escutar o grito da sentinela dando o alarme - talvez um tiro para o alto. E logo em seguida o alarido da tropa, os portões se abrindo, os soldados, dezenas deles, descendo a encosta do Morro da Quitéria, berrando raivosos. [...]. (p.24-25)

Manuel Francisco surgiu ao lado de Joanna de repente. Havia deslizado pelo poste, sem a garota perceber. Ela assustou-se, mas conteve-se ligeira, e Manuel Francisco agarrou a mão dela, puxando-a para começarem a correr.

"Obrigada, senhora Lua", disse Joanna para si mesma, espiando rapidamente para o alto. Mas, no instante seguinte, lembrou-se que era cedo para agradecer - ainda não estavam a salvo. $E$ foi então que seus olhos bateram na sacola que Manuel Francisco agora carregava às costas. Tinha volume, o fundo arriava. O horror de Joanna era que quase podia adivinhar as formas do que ia ali dentro. (AGUIAR, 2012, p.36)

Conforme a sentença, além de ser decapitado e esquartejado por soldados a serviço da Coroa portuguesa, a cabeça de Tiradentes deveria ficar exposta em praça pública até apodrecer. Porém, Manuel Francisco rouba a 
cabeça do morto e a leva para enterrar em uma caverna distante da cidade, afrontando o Governo. A partir desse ato, considerado pelo próprio Manuel Francisco como "espantoso", transcorrem as demais ações da narrativa, que é recheada de aventura e suspense. Manuel Francisco e Joanna passam então, indiretamente, a ser também parte do grupo de inconfidentes, e precisam fugir da perseguição dos representantes da Coroa em Vila Rica, no caso o governador geral das Minas Gerais, Visconde de Barbacena, representado pelo capitão da guarda, José Romão. Inclusive foi uma ação do governador, a realização de um baile em comemoração à repressão da revolta e à morte de Tiradentes, que consistiu na principal força motriz para o ato praticado pelo jovem casal:

- Como seu pai sabia que não iluminariam a praça com tochas? Era o mais lógico, não era? - perguntou a garota. [...]

- Não sei como ele sabia - respondeu Manoel Francisco em voz sumida. - Ele somente disse que não haveria tochas na praça. Nem soldados. Que os únicos de guarda estariam nas guaritas das muralhas, a distância.

- E como ele sabia disso também?

Manuel Francisco deu de ombros. O que poderia responder? Que seu pai recebera essas informações de seus anjos? Seria a resposta que o entalhador lhe daria. 
- Como ele pôde pedir a você que fizesse isso? - indagou Joanna.

- Ele não pediu, eu é que disse a ele que iria fazer... Fiz questão!

Joanna soltou um muxoxo. Não estava nem um pouco surpresa. Manuel Francisco quis explicar:

- Quando ele me contou da festa que o governador deu ontem, em comemoração a... a... Joanna, você não pode imaginar o que diziam, a alegria deles, os insultos...

(AGUIAR, 2012, p.26-27)

Fica claro, em determinados momentos da narrativa, que a relação de Aleijadinho com os inconfidentes decorre de anos. No final do primeiro capítulo da narrativa, retomase uma ocasião em que Manuel Francisco, ainda menino, ganha um peão de Tiradentes. Este havia ido à oficina de Aleijadinho para participar de uma reunião secreta, e levara o brinquedo para agradar a criança. Essa era uma lembrança afetiva de Manuel Francisco em relação ao alferes, a qual denota também que os membros da Conjuração planejavam a rebelião há alguns anos. Em outra parte do texto, no trecho datado como [Vila Rica, abril de 1789], há o relato de uma importante reunião entre os inconfidentes:

Para chegar à chácara afastada, no Morro do Cruzeiro, onde os conjurados realizavam suas reuniões clandestinas, era preciso passar junto a um logradouro que em todos 
provocava calafrios: a Praça da Forca. Ali eram executados os escravos fugitivos e os contrabandistas de ouro e gemas.

- É como se fosse uma premonição! resmungou Antônio Francisco, já então chamado de Aleijadinho, quando o dono da propriedade, o tenente-coronel Francisco de Paula Freire Andrade, abriu-Ihe a porta. Estou atrasado?

- O alferes [Tiradentes] já está aqui respondeu o tenente-coronel carrancudo. 0 Aleijadinho frequentemente chegava depois da hora marcada, alegando ou dificuldade de locomoção ou algum problema que tivera de resolver na oficina. Andrade havia tempos convencera-se de que seu companheiro de conspiração se atrasasse por algum vício próprio de artistas. Até porque Cláudio Manuel, poeta e dramaturgo, tinha o mesmo hábito. - Procure na sala dos fundos. Está conversando com o Cláudio Manuel e com o sargento Luís Vaz. (AGUIAR, 2012, p.83)

No encontro, Tiradentes fala de seu propósito de ir buscar ajuda no Rio de Janeiro para reforçar a rebelião contra os desmandos da Coroa. Esses foram os últimos momentos dos amigos junto ao líder da Conjuração, o qual depois seria preso por três anos e, por fim, enforcado e esquartejado. Nessa ocasião, Tiradentes reconhece a grandeza de Aleijadinho e roga que este salve sua arte:

- Eu sou um organizador, meu amigo. E um soldado. Capazes de fazer o que eu faço há e 
haverá muitos. Mas você é o único que pode imortalizar nossa luta e impregnar nossos ideais no espírito das pessoas. Basta uma de suas esculturas para mostrar que todos os opressores que nos acuam e principalmente o poder deles são mesquinhos, ínfimos, diante da grandiosidade do que um ser humano de mente e espírito livres pode criar. Aliás... Isso é liberdade! (AGUIAR, 2012, p.91)

Sobre o filho de Aleijadinho, Manoel Francisco, embora haja registros sobre sua existência histórica, não só o seu protagonismo enquanto cúmplice dos inconfidentes, mas também a existência de uma relação conflituosa entre este e o pai ficam também por conta da ficção. Em vários momentos, essa relação tensa, que oscila entre amor e repulsa, é explicitada. No trecho identificado como "Vilarejo de Espera, 1792", Manuel Francisco presta contas a Aleijadinho sobre a sua missão - o roubo da cabeça do líder dos inconfidentes -, momento em que rememora tempos de alegria e cumplicidade com o seu progenitor, quando este era a sua grande paixão. No presente, constata, entretanto, que não sente mais a mesma proximidade, ao contrário, sente que cada vez mais não reconhece, na figura do entalhador, a de seu querido pai. Da mesma maneira, verificamos, no fragmento datado como "Matriz de Nossa Senhora da Conceição de Antônio Dias, Vila Rica, Minas Gerais, 1767", que a relação entre Aleijadinho e seu pai, 
Manuel Francisco Lisboa - mesmo nome atribuído ao neto -, também fora problemática, chegando ao extremo quando eles tiveram um grave desentendimento e romperam relações definitivamente. $\mathrm{O}$ pai de Aleijadinho, igualmente entalhador, passara a profissão ao filho e, nessa ocasião, eles se desentenderam justamente em virtude de uma obra que realizavam conjuntamente. Em um diálogo transcorrido entre Manuel Francisco e Joanna, ambos falam sobre a doença de Aleijadinho:

- Você acha que ele não percebe esse seu nojo dele?

- Não é verdade! Não tenho nojo dele! - replicou o rapaz, tão irritado que quase engasgou.

- Pois parece. Muito. Do jeito que você fala, é quase como se descrevesse quando os dois estão frente a frente.

- Você nunca assistiu a um encontro desses!

- Mas é como se o presenciasse... Posso ver como é... Quando você o olha... e nunca se aproxima dele. Nunca... o abraça!

- E ele? Ele me abraça?

- E se tentasse? O que você faria? Deixaria ou recusaria?

Manuel Francisco baixou os olhos, por instantes, e foi ainda sem erguê-los, o rosto vermelho e os lábios trêmulos, que resmungou entredentes: 
- Cale a boca. Você não sabe o que diz. Não pode saber. (AGUIAR, 2012, p.105)

No trecho reproduzido e na sequência dessa fala, o rapaz confessa a dificuldade que tem de se relacionar com o pai e o medo que possui de ter herdado dele a doença. Outro relato em flashback (AGUIAR, 2012, p.109-112) retoma uma ocasião em que Manuel Francisco, contando com a idade de treze anos, é levado às pressas à casa do pai. Aleijadinho, que passava por uma crise aguda de dor, pede ao filho que lhe ampute os dedos com uma faca, e o menino, sem coragem de atender ao pedido do pai, foge desesperado. Mais ao final da narrativa, no capítulo onze, o fragmento identificado por "Igreja de São Francisco de Assis, Vila Rica, Minas Gerais, 1812" mostra o retorno de Aleijadinho e do filho a Vila Rica, vinte anos depois dos acontecimentos que os levaram a ir embora daquele local. O entalhador viera para ver a pintura projetada por ele e executada por mestre Ataíde na Igreja de São Francisco de Assis. Nessa altura da narrativa, parece que a relação entre pai e filho, este agora já mais amadurecido, mudara bastante. Manuel Francisco se monstra gentil e afetuoso com o pai. Aleijadinho, em determinado momento, pergunta ao filho sobre a tríada de anjos esculpidos em pedras sabão que lhe dera ainda na adolescência e este lhe mostra o objeto, demonstrando o valor afetivo que atribuíra à peça: 
Manuel Francisco tirou a peça do embornal e a exibiu. O Aleijadinho tranquilizou-se, então arriou o corpo na maca, e Manuel Francisco disse:

- Será tudo feito como o senhor determinou. - A seguir, fixou os olhos nos olhos do pai. Havia coisas que poderiam ser ditas. Muitas coisas. Ambos sabiam disso. No entanto, ao mesmo tempo, sabiam também que não precisavam mais ser ditas. Manuel Francisco apertou com delicadeza as mãos mutiladas do entalhador. Sentiu os ossos dele, retorcidos, ranger, mas não largou; suavizou ainda mais o aperto, somente, e seus olhos estavam úmidos quando ele falou: - Vamos para casa meu pai. (AGUIAR, 2012, p.207)

Na cena transcrita, notamos que pai e filho chegam a um ponto de conciliação, quando as mágoas são substituídas por carinho e afeto. Nesse sentido, lembramos o que Teresa Colomer (2003) verifica em sua caracterização sobre e narrativa juvenil contemporânea, que a repercussão afetiva da conduta dos pais sobre a vida de personagens adolescentes e jovens tem sido um tema bastante explorado nesses textos, especialmente dentro de uma linha de inovação temática que enfatiza os conflitos psicológicos desses personagens. Tais conflitos quase sempre aparecem dentro de um processo formativo também recorrente na Literatura Juvenil (LJ) e, à medida que os jovens amadurecem, alcançando a vida adulta, é muito comum que ocorra a assunção desses 
problemas, algo que verificamos na narrativa de Os Anjos Contam Histórias.

Ao procurarmos apontar aspectos da metaficção historiográfica na construção narrativa de Os Anjos Contam Histórias é preciso mais uma vez lembrar, com Linda Hutcheon, os dois aspectos fundamentais desse tipo de ficção: o seu carácter metadiscursivo e a sua relação com a historiografia, pois ambos os gêneros, o histórico e o ficcional, apresentam convenções comuns em termos discursivos (HUTCHEON, 1991, p.148), portanto a historiografia nada mais é do que um artefato verbal e, nesse sentido, literário. Assim, a metaficção historiográfica permite realizar uma crítica da história tradicional ao propor, conscientemente, uma outra leitura do discurso historiográfico, ao revisitá-lo ironicamente, desconfiando dessa narrativa oficial. O modo mais recorrente de fazer isso é se voltando para as figuras periféricas ou excêntricas, fora do centro, isto é, aquelas que estão à margem do discurso historiográfico. Na narrativa em análise, as personagens centrais para a trama são marcadas por essa excentricidade: seja uma personalidade histórica de renome como Aleijadinho, sejam aquelas secundárias para a historiografia, mas centrais para a ficção, como Manuel Francisco e Joanna Lopes, filho e nora do artista mineiro. 
Aleijadinho, tanto o histórico quanto o ficcional, não teve sua genialidade reconhecida enquanto ainda era vivo e viveu na invisibilidade: era mulato, sofria de uma doença grave que o deixou aleijado; tornou-se uma figura extremamente feia e repulsiva, que se escondia por detrás de chapéus e capotes. Ninguém soube explicar como, mesmo atrofiado e com os instrumentos de trabalho amarrados aos tocos das mãos, conseguiu produzir uma obra de arte tão gigantesca. Mas essa arte também era excêntrica porque não seguia os modelos clássicos universais. No fragmento datado como "Congonhas do Campo, átrio do Santuário do Bom Jesus de Matosinhos, 1812", é retrato o diálogo de dois estudiosos vindos de Coimbra, os quais analisam a obra de Aleijadinho, parte do qual reproduzimos a seguir:

- Muito, muito longe da perfeição!

Ao que o outro replicou:

- Concordo, meu caro. Não é preciso ser profissional para reconhecer nelas a incorreção do desenho, a pouca harmonia e a falta de proporção de certas formas. Cabeças mal contornadas, proporções mal guardadas, corpos por demais espessos e curtos, e outros muitos defeitos capitais e de detalhes, revelando que esses profetas são filhos de um cinzel tosco e ignorante. Parece que essas estátuas... e ouça bem que não as chamo de esculturas... são cópias grosseiras e incorretas de belos modelos de arte que 
o escultor... ou deveria dizer, artesão e seus empregados... tinham diante dos olhos ou impressos na imaginação.

- Todavia - suspirou o primeiro -, é fato, impressionam. As atitudes em geral são características, imponentes e majestosas, as roupagens dispostas com arte, e por vezes o cinzel do rude escultor soube imprimir às fisionomias uma expressão digna dos profetas. (AGUIAR, 2012, p.192)

No trecho acima, identificamos a incompreensão sobre a arte do escultor, que divide os observadores entre 0 desmerecimento e o fascínio. Mesmo não seguindo os padrões da arte sacra europeia, ou justamente por não segui-los, a obra de Aleijadinho é singular e impactante.

O personagem Manuel Francisco, de maneira semelhante ao pai, passou grande parte da vida sentindo-se acuado porque sentia o olhar de estranhamento das pessoas, sentia medo de ter herdado a doença paterna e de ser também ele um aleijado. Revela isso em uma conversa com Joanna:

- O sangue dele está em mim. É meu sangue também.

- Não acredito que você tenha medo de ficar doente também, daqui a uns anos. É isso que o perturba tanto? Está sofrendo antes da hora por algo que pode nem acontecer. Você não é um medroso, Manuel Francisco!

- Não! Daqui a alguns anos, não. Já gora. Correndo nas minhas veias. $O$ horror que me 
dá é que a doença dele eu a tenha também. Mesmo que nunca fique deformado, eu sou doente. Eu sou... como ele! - O garoto soltou um soluço e emudeceu de novo, buscando palavras. - Às vezes, na rua, quando pego alguém me olhando, penso se a pessoa está vendo a doença em mim. Eu devia me afastar dele de vez, daí... essa maldição acabava. (AGUIAR, 2012, p.106-107)

Além da possível herança maldita simbolizada pela doença, Manuel Francisco também era mulato e fruto da relação do pai com uma escrava, assim como acontecera com o próprio Aleijadinho.

A nora, Joanna Lopes, fora desde sempre apontada como a "filha da bruxa", pois a mãe era parteira e curandeira local; conhecia ervas, chás curativos e os mistérios da lua. A filha, ao herdar os conhecimentos maternos, continuará a mesma saga familiar, tornando-se também ela "bruxa". Ademais, por amar um homem que passou boa parte da vida fugindo de seus perseguidores políticos, Joanna sofreu a sina de viver na solidão e na angústia de ter seu amor longe de si. Em uma das cartas transcritas no interior da narrativa, ela confessa o seu pesar:

Ah, esse amor que me condena, eu pressinto, a uma vida de apreensão e de saudade! Ah, essa opressão da perda iminente, do espaço deixado vazio! $E$ nesses anos que estão reservados para mim, na jornada do meu coração, quantas vezes aguardarei, 
resignada, que um estranho bata à nossa porta, encarregado de me avisar que você jaz frio e abandonado, em um lugar ermo, desconhecido. [...] Sei sim que o amarei mais ainda, à medida que os anos me acrescentarem rugas, calos e cicatrizes. (AGUIAR, 2012, p.146)

Assim, essas figuras históricas recriadas ficcionalmente são todas marcadas pela excentricidade, por isso desenvolvem um olhar à margem da sociedade em que estão inseridas e vivem em constante confronto com o poder instituído. Nesse sentido, dois personagens representam de maneira bem evidente esse embate ideológico, como procuramos mostrar na sequência.

\section{O EMBATE DA ARTE COM O PODER OFICIAL}

No interior da narrativa, percebemos especialmente no enfrentamento entre Aleijadinho e o capitão da guarda, José Romão, um embate entre a arte e o poder institucional de um governo autoritário e violento. Na sequência narrativa datada como "Vilarejo de Espera, 1792", vemos o enfrentamento entre José Romão e Aleijadinho. Os dois estabelecem um diálogo tenso e o capitão procura indícios de que o entalhador está envolvido com os conjuradores. No trecho retratado a seguir, notamos o incomodo de José Romão em relação à arte de Aleijadinho: 
Tinha ainda outra razão para a estranha sensação que começava a tomá-lo. Num canto da oficina, havia uma peça de madeira quase da altura dele. Era uma tríade de anjos, enfeixados como num buquê $e$ cercados por um friso - parte da portada de alguma igreja, de pedra-sabão. José Romão os enxergara pelo canto dos olhos, e agora não podia mais evitar espiá-los, de esguelha, de instante em instante, como se a imagem o tivesse capturado. Volta e meia, desviava a cabeça para aquele lado - um movimento compulsivo, que se esforçava para disfarçar. Entretanto, podia jurar que os três rostos rechonchudos e de cabelos acentuadamente ondulados sorriam para ele, com expressão tão debochada como o tom usado pelo homem que os esculpira.

(AGUIAR, 2012, p.71)

No excerto acima, fica claro que Aleijadinho usa sua arte como forma de protesto, que não se amedronta diante do poder oficial e que os representantes deste poder não são capazes de alcançar o significado desta arte.

Mais adiante, em diálogo com o governador, Romão fala de suas suspeitas a respeito de Aleijadinho, insiste que tem fortes indícios de que o entalhador seria um conjurador e, embora o visconde não the dê ouvidos e peça que deixe o artista sossegado, já que este está trabalhando em uma encomenda importante, expressa a raiva que sente pelo artista e promete para si mesmo ficar no seu encalço. Em 
uma cena na igreja de São Francisco de Assis, durante a missa de ação de graças e início dos preparativos para a procissão de Corpus Christi, José Romão, mais uma vez, reluta em entrar no local por sentir que os anjos sobre a portada estão olhando para ele com ar de deboche:

Ultimamente, no que desviava seus olhos para cima ou para algum canto, dava com aqueles mesmos anjinhos, de olhar maroto (e os achava mais marotos a cada dia). Era como se o estivessem vigiando, e não ele - José Romão, capitação da guarda da Fortaleza do Morro de Santa Quitéria e ajudante de ordens de Sua Graça, o visconde de Barbacena, governador da Província das Minas Gerais - que vigiasse a todos naquela cidade. (AGUIAR, 2012, p.116)

No capítulo oitavo, "Com cara de santarrão", Aleijadinho entrega a encomenda que havia sido feita pelo governador para a procissão de Corpus Christi. Durante a caminhada, todos são surpreendidos ao verificarem que a estátua de São Jorge, esculpida por Aleijadinho para abrir a procissão, nada mais é do que uma caricatura do capitão José Romão. Este fica cego de raiva ao perceber que o entalhador finalmente o está afrontando abertamente. Em virtude disso, Romão comete uma série de desatinos que acabam pondo fim, tragicamente, à procissão e levam à sua própria demissão do cargo de capitão da guarda. O governador, enfurecido 
pelos acontecimentos e pelo fato de o capitão ter provocado a morte de um escravo que era protegido de uma senhora lisboeta a quem estava cortejando, o depõe do cargo, manda prendê-lo e soltar todos os demais prisioneiros da Fortaleza. Quando o novo comandante da guarda vai ao encontro de Aleijadinho, este já havia deixado Vila Rica rumo à cidade de Congonhas do Campo.

Esse embate entre o artista e o capitão representa, de alguma maneira, a própria relação tensa e autoritária entre o Governo e a população mais oprimida. O fim humilhante do capitão e a fuga de Aleijadinho acabam sinalizando uma esperança de liberdade para os revoltosos que representam uma parcela da população que não se curvou à tirania da Coroa portuguesa.

A narrativa explora ainda a ideia de que na obra de Aleijadinho existem indícios de que sua arte perpetua a ação dos conjuradores, eternizando a resistência ao poder oficial. Vejamos o fragmento em que Manuel Francisco e Joanna analisam a obra dos doze profetas, erguida no Santuário do Bom Jesus de Matosinhos, em Congonhas do Campo:

- Pense só... Há doze profetas aqui, mas nem todos são os principais profetas bíblicos. Há profetas menores, e até mesmo um deles que nem profeta é, mas secretário de um profeta. 
- Eu não conheço a Bíblia tanto assim disse, com ar zombeteiro, Joanna.

- Nem eu - confessou Manuel Francisco. Quase ninguém conhece. Mas quem conhece estranha: por que meu pai escolheu esses personagens e não outros?

Joanna girou o corpo lentamente, maravilhada:

- Diga de novo... Quem são eles?

- Começando pelo meu preferido, Jonas...

- Tiradentes.

- Isso mesmo. Isaías é Domingos de Abreu Vieira, compadre do alferes. Jeremias, o tenente-coronel Francisco de Paula Freire Andrade. Ezequiel é o bravo sargento Luís Vaz de Toledo Pisa, que morreu no exílio. $\mathrm{E}$ Daniel, Tomás Antônio Gonzaga. Esses são os profetas maiores. Baruc era secretário de Jeremias, e representa o médico Amaral Gurgel, natural de Parati, que foi um refúgio de piratas, depois de maçons. Os profetas menores são Oseias, que representa Inácio de Alvarenga; Abdias, que é José Álvares Maciel; Naum, que é o Oliveira Lopes; e Habaruc, Domingos Vidal Barbosa.

- E Joel...

- Joel é o poeta Cláudio Manuel da Costa, amigo de juventude do meu pai. E tem por último Amós, com esse rosto negro, dedos deformados e o chapéu, um barrete frígio, que nem os republicanos franceses...

$-\ldots$ seu pai.

- Isso. Ele se colocou entre os Inconfidentes. Uma confissão cifrada! E repetiu-a de outra 
maneira também. Mas essa não adivinhei. Ele é que me contou...

(AGUIAR, 2012, p.196-197)

No diálogo entre Joanna e Manuel Francisco, este explicita a homenagem cifrada feita por Aleijadinho aos inconfidentes, confirmando o que sentenciara Tiradentes, que a grandiosidade da arte do entalhador iria tornar ínfimos e mesquinhos todos os seus inimigos. Além disso, na obra os doze profetas, Aleijadinho teria representado a si mesmo em uma das esculturas, deixando assim registrado, para a posteridade, a sua união aos revoltosos da Inconfidência Mineira.

\section{ALGUMAS CONSIDERAÇÕES}

Ao longo da nossa análise, procuramos enfocar aspectos paratextuais da obra que fossem importante para a leitura proposta, evidenciando que a obra, desde a sua capa, apresenta uma narrativa profundamente imbricada com a arte de Aleijadinho, que os pré e pós-textos vão apontando para a base histórica em que se assenta a narrativa, ao mesmo tempo em que nos lembram que se trata de um texto ficcional e, portanto, livre de qualquer compromisso com a verdade, comprometido, isso sim, com a invenção e com a trama.

Verificamos como o texto explora, enquanto narrativa juvenil, o processo de amadurecimento de Manuel Francisco 
e Joanna, os quais, ainda muito jovens, envolvem-se em arriscadas conspirações contra o Governo; assim como a relação conflituosa entre o jovem Manuel Francisco e o pai, demonstrando que, com o tempo, ocorre a assunção desse conflito.

Procuramos enfatizar, por fim, a releitura histórica no interior da narrativa olhando para três personagens centrais para esse processo: o filho de Aleijadinho, Manuel Francisco, a nora, Joanna Lopes, e o pai, sogro e artista Aleijadinho, demonstrando que a revisão da história oficial dentro da narrativa se dá pelo viés da excentricidade dessas personagens, o que permite uma (re)leitura da história oficial a partir da margem.

\section{REFERÊNCIAS}

AGUIAR, Luiz Antonio (2012). Os anjos contam histórias. Rubem Filho (Ilustr.). São Paulo: Ed. Melhoramentos.

BAGOLIN, Luiz Armando (2009). "O Aleijadinho: monstro herói". Estudos Avançados, 23(65), 353-358.

BURY, John (2006). "Antônio Francisco Lisboa, o Aleijadinho". In Arte e arquitetura no Brasil colonial. Myriam Andrade Ribeiro de Oliveira (Org.). Brasília, DF: IPHAN/MONUMENTA, p.86-103. In http://portal.iphan. gov.br/uploads/publicacao/ColObrRef_ArquiteturaArteBrasilColonial.pdf Acesso em 5.Ago.2019.

COLOMER, Teresa (2003). A formação do leitor literário: narrativa infantil e juvenil atual. Laura Sandroni (Trad.). São Paulo: Global.

HUTCHEON, Linda (1991). Poética do pós-modernismo: história, teoria, ficção. Ricardo Cruz (Trad.). Rio de Janeiro: Imago Editora. 
Silvani Lopes Lima é Doutoranda em Letras pela UPF (2016-atual) e Mestre em Letras pela UFSM (2006). Atua como Professora EBTT no IFRS - Campus Ibirubá. Entre suas produções, destacam-se: SCHOLL, M.; LIMA, S. L. A leitura digital no contexto escolar: desafios e possibilidades. Revista Thema, 15, p.269-281, 2018; LIMA, S. L. O resgate e a subversão do mito histórico em $O$ conquistador, de Almeida Faria. DLCV (UFPB), v.1, p.105-123, 2017; SOUSA, L. B. de; LIMA, S. L. Clube de leitura como espaço para formação de leitores: entre o sonho e a realidade. In: $V$ Simpósio Internacional e IX Nacional de Literatura e Informática. São Leopoldo (RS): Casa Lieira, 2018, p.353-364; LIMA, S. L. O hipertexto no impresso: uma leitura da obra Todos contra D@nte. 70 Seminário de Literatura Infantile Juvenil. Florianópolis: UFSC; UNISUL, 2017, p.904-912. E-mail: slopeslima@gmail.com.

ORCID iD: https://orcid.org/0000-0001-7899-1957

Fabiane Verardi é Doutora em Letras (Teoria Literária) pela PUCRS (2004), Pós-Doutora pela Universidade de Coimbra (2019) e Mestre em Letras (Teoria Literária) pela PUCRS (1999). Atualmente é Professora Titular II da Universidade de Passo Fundo, no curso de Letras, no Programa de Pós-Graduação em Letras e Coordenadora das Jornadas Literárias de Passo Fundo. Vice-Coordenadora do Grupo de Trabalho Leitura e Literatura Infantil e Juvenil da Associação Nacional de PósGraduação e Pesquisa em Letras e Linguística (ANPOLL), biênio 2018-2020. Desenvolve projetos na linha de pesquisa de Leitura e Formação de Leitor, focalizando seus trabalhos na questão da leitura na escola, metodologias de ensino da literatura infantil e juvenil. É líder do Grupo de Pesquisa CNPq: Sobre Ensino de Literatura. E-mail: fabianevb@uol.com.br.

ORCID iD: https://orcid.org/0000-0002-6868-3616 